\title{
Hyposmotic challenge modulates function of L-type calcium channel in rat ventricular myocytes through protein kinase $\mathrm{C}$
}

\author{
An-tao LUO ${ }^{1}$, Hong-yan $\mathrm{LUO}^{1}$, Xin-wu HU⿱1${ }^{1}$, Lin-lin GAO ${ }^{1}$, Hua-min LIANG ${ }^{1}$, Ming TANG ${ }^{1, *}$, Jürgen HESCHELER ${ }^{2}$ \\ ${ }^{1}$ Department of Physiology, Tongji Medical College, Huazhong University of Science and Technology, Wuhan 430030, China; ${ }^{2}$ Institute \\ of Physiology, University of Cologne, D-50931 Cologne, Germany
}

\begin{abstract}
Aim: To study the effects and mechanisms by which hyposmotic challenge modulate function of $L$-type calcium current $\left(I_{\mathrm{Ca}, \mathrm{L}}\right)$ in rat ventricular myocytes.

Methods: The whole-cell patch-clamp techniques were used to record $I_{\mathrm{Ca}, \mathrm{L}}$ in rat ventricular myocytes.

Results: Hyposmotic challenge( 220 mosmol/L) induced biphasic changes of $I_{\text {Ca,L }}$, a transient increase followed by a sustained decrease. $I_{\mathrm{Ca}, \mathrm{L}}$ increased by $19.1 \% \pm 6.1 \%$ after short exposure (within $3 \mathrm{~min}$ ) to hyposmotic solution. On the contrary, long hyposmotic challenge $\left(10 \mathrm{~min}\right.$ ) decreased $I_{\mathrm{Ca}, \mathrm{L}}$ to $78.1 \% \pm 11.0 \%$ of control, caused the inactivation of $I_{\mathrm{Ca}, \mathrm{L}}$, and shifted the steady-state inactivation curve of $I_{\mathrm{Ca}, \mathrm{L}}$ to the right. The decreased $I_{\mathrm{Ca}, \mathrm{L}}$ induced by hyposmotic swelling was reversed by isoproterenol or protein kinase A (PKA) activator foskolin. Hyposmotic swelling also reduced the stimulated $I_{\mathrm{Ca}, \mathrm{L}}$ by isoproterenol or foskolin. PKA inhibitor $\mathrm{H}-89$ abolished swelling-induced transient increase of $I_{\mathrm{Ca}, \mathrm{L}}$, but did not affect the swelling-induced sustained decrease of $I_{\mathrm{Ca}, \mathrm{L}}$. NO donor SNAP and protein kinase G (PKG) inhibitor Rp-8-Br-PET-cGMPS did not interfere with swelling-induced biphasic changes of $I_{\mathrm{Ca}, \mathrm{L}}$. Protein kinase $\mathrm{C}(\mathrm{PKC})$ activator PMA decreased $I_{\mathrm{Ca}, \mathrm{L}}$ and hyposmotic solution with PMA reverted the decreased $I_{\mathrm{Ca}, \mathrm{L}}$ by PMA. PKC inhibitor BIM prevented the swelling-induced biphasic changes of $I_{\mathrm{Ca}, \mathrm{L}}$.

Conclusion: Hyposmotic challenge induced biphasic changes of $I_{\mathrm{Ca}, \mathrm{L}}$, a transient increase followed by a sustained decrease, in rat ventricular myocytes through PKC pathway, but not PKG pathway. PKA system could be responsible for the transient increase of $I_{\text {Ca,L }}$ during short exposure to hyposmotic solution.
\end{abstract}

Keywords: hypotonic solution; calcium channels; patch-clamp techniques; protein kinase C; protein kinase A; cardiac myocytes

Acta Pharmacologica Sinica (2010) 31: 1438-1446; doi: 10.1038/aps.2010.112; published online 18 Oct 2010

\section{Introduction}

The osmolarity of body fluids is normally very tightly regulated so that most cells do not experience changes in osmotic pressure under physiological conditions ${ }^{[1]}$, but osmotic changes can occur in pathological states. Extensive evidence indicates that cardiac cell swelling occurs under abnormal conditions such as ischemia and reperfusion ${ }^{[2-6]}$. It has been shown that cell swelling can modulate the function of a number of membrane channels and ion transporters. These effects will lead to changes in the cardiac electrical activity and may contribute to arrhythmogenesis under pathological conditions ${ }^{[7,8]}$. Swelling can also reduce the efficacy of some antiarrhythmic drugs and render them less effective during ischemia/reperfusion ${ }^{[9-11]}$.

\footnotetext{
* To whom correspondence should be addressed. E-mail mtang@mails.tjmu.edu.cn

Received 2010-03-22 Accepted 2010-07-05
}

The cardiac $L$-type $\mathrm{Ca}^{2+}$ channel $\left(I_{\mathrm{Ca}, \mathrm{L}}\right)$ plays a critical role in cardiac excitability and in excitation-contraction coupling. However, the effect of cell swelling on cardiac $I_{\mathrm{Ca}, \mathrm{L}}$ remains controversial. For example, some studies have shown clear increases in $I_{\mathrm{Ca}, \mathrm{L}}{ }^{[12-14]}$, while others have shown a decrease in $I_{\mathrm{Ca}, \mathrm{L}}{ }^{[15,16]}$ or no effect ${ }^{[10,17]}$. Some authors have even demonstrated biphasic effects on $I_{\mathrm{Ca}, \mathrm{L}}$, an increase followed by a more sustained decrease ${ }^{[18]}$. Previous reports indicated that osmotic swelling increases $I_{\mathrm{Ca}, \mathrm{L}}$ in neonatal rat ventricular myocytes ${ }^{[14]}$, but decreases $I_{\mathrm{Ca}, \mathrm{L}}$ in adult rat ventricular myocytes ${ }^{[16]}$. But these reports did not explore the mechanism underlying the changes of $I_{\mathrm{Ca}, \mathrm{L}}$. Thus it is important to unveil the details of osmotic regulation on $I_{\mathrm{Ca}, \mathrm{L}}$ and the underlying mechanisms, which may provide clues to develop novel therapeutic approaches useful for pathological conditions that induce cell swelling. Therefore in this study we have investigated the consequences and mechanisms by which cell swelling modulates $I_{\mathrm{Ca}, \mathrm{L}}$. 


\section{Materials and methods}

\section{Solutions and drugs}

The Tyrode solution contained (in mmol/L): $135 \mathrm{NaCl}, 5.4$ $\mathrm{KCl}, 1.8 \mathrm{CaCl}_{2}, 1 \mathrm{MgCl}_{2}, 0.33 \mathrm{NaH}_{2} \mathrm{PO}_{4}, 10$ glucose, and 10 HEPES, pH 7.4 with $\mathrm{NaOH}$. The $\mathrm{KB}$ solution contained (in mmol/L): $70 \mathrm{KOH}, 40 \mathrm{KCl}, 1 \mathrm{MgCl}_{2}, 20 \mathrm{KH}_{2} \mathrm{PO}_{4}, 20$ taurine, 50 glutamic acid, 0.5 EGTA, 10 glucose, and 10 HEPES, pH 7.4 with $\mathrm{KOH}$. The pipette solution used to record $I_{\mathrm{Ca}, \mathrm{L}}$ contained (in mmol/L): $115 \mathrm{CsCl}, 20$ TEA-Cl, 5 MgATP, $0.1 \mathrm{Na}_{2}$ GTP, 10 phosphocreatine, $1 \mathrm{CaCl}_{2}, 10$ EGTA, and $10 \mathrm{HEPES}$, $\mathrm{pH} 7.2$ with $\mathrm{CsOH}$. The standard isosmotic bath solution ( 300 mosmol/L) used to record $I_{\mathrm{Ca}, \mathrm{L}}$ was composed of (in mmol/L) 88 choline chloride, $5.4 \mathrm{CsCl}, 1 \mathrm{MgCl}_{2}, 1.8 \mathrm{CaCl}_{2}, 10$ glucose, 10 HEPES, and 96 D-mannitol, pH 7.4 with $\mathrm{CsOH}^{[19]}$. D-mannitol concentrations were modified to be $15 \mathrm{mmol} / \mathrm{L}$ $(\sim 220 \mathrm{mosmol} / \mathrm{L})^{[19,20]}$ and $177 \mathrm{mmol} / \mathrm{L}(\sim 380 \mathrm{mosmol} / \mathrm{L})$ for the standard hyposmotic solution and hyperosmotic solution, respectively. The osmolarity of the solutions was calculated by the formula: mosmol/ $\mathrm{L}=\sum \varphi_{\mathrm{i}} n_{\mathrm{i}} C_{\mathrm{i}}$, where $\Phi$ is the osmotic coefficient; $n$ is the number of particles into which a molecule dissociates; $C$ is the molar concentration of the solute; the index $i$ represents the identity of a particular solute ${ }^{[21]}$.

Collagenase type I was obtained from Gibico (GIBCO TM, Invitrogen, Paisley, UK). Isoproterenol hydrochlordie, forskolin, H-89, phorbol 12-myristate 13-acetate (PMA), Bisindolylmaleimide IV (BIM), S-nitroso-N-acetylpenicillamine (SNAP), Rp-8-Br-PET-cGMPS, TEA-Cl, CsCl, CsOH, MgATP, and $\mathrm{Na}_{2}$ GTP were purchased from Sigma Chemical (Saint Louis, MO, USA). Forskolin, H-89, PMA, and BIM were dissolved in DMSO and diluted into the test solution to obtain the required concentration immediately before use. The final concentration of DMSO in the test solution did not exceed $0.1 \%$. We confirmed that DMSO at this concentration had no effect on $I_{\mathrm{Ca}, \mathrm{L}}$. H-89 and Rp-8-Br-PET-cGMPS were dissolved into the pipette solution at the final concentration indicated in the text.

\section{Isolation of myocytes}

Adult female Sprague-Dawley rats (220-260 g) were anesthetized with pentobarbital sodium (30 mg/ kg, ip) 20 min after an intraperitoneal injection of $2000 \mathrm{U}$ heparin. Hearts were excised rapidly and perfused retrogradely on a langendorff apparatus with $\mathrm{Ca}^{2+}$-free Tyrode solution for $5 \mathrm{~min}$; subsequently, the perfusate was switched to an enzyme-containing solution $[0.3 \mathrm{~g} / \mathrm{L}$ collagenase type $\mathrm{I}, 0.5 \mathrm{~g} / \mathrm{L}$ bovine serum albumin (BSA) in the same solution] for 25-30 min. The perfusate was finally changed to a KB solution for $5 \mathrm{~min}$. These perfusates were bubbled with $100 \% \mathrm{O}_{2}$ and maintained at $37^{\circ} \mathrm{C}$. The ventricles were cut into small chunks and gently agitated in $\mathrm{KB}$ solution. The cells were filtered through nylon mesh and stored in $\mathrm{KB}$ solution at $4{ }^{\circ} \mathrm{C}$ until use. All procedures met the Guide for the Care and Use of Laboratory Animals of Hubei Province.

\section{Current recordings}

Before patch clamp recording, cells were transferred onto a coverslip in a recording chamber that was mounted on the stage of an inverted microscope (Zeiss, Germany). The recording chamber was continuously perfused with bath solution. Conventional whole-cell patch clamp was performed at room temperature $\left(20-22{ }^{\circ} \mathrm{C}\right)$ using an Axopatch 200A amplifier and Digidata 1200 A/D converter (Axon instruments, Union city, CA, USA). The patch electrodes had resistances of 1.5-2.5 M $\Omega$ when filled with the pipette solutions. Capacitance and series resistances were adjusted to obtain minimal contribution of the capacitive transients. A 50\%-80\% compensation of the series resistance was usually achieved without ringing. Currents were filtered at $2 \mathrm{kHz}$, digitized at $10 \mathrm{kHz}$ and stored on a computer hard disk for further analysis.

To measure $I_{\mathrm{Ca}, \mathrm{L}}$, cells were voltage clamped at a holding potential (HP) of $-80 \mathrm{mV}$. A $50-\mathrm{ms}$ prepulse to $-40 \mathrm{mV}$ was used to inactivate $I_{\mathrm{Ca}, \mathrm{TTX}}{ }^{[22]}$, and $I_{\mathrm{Ca}, \mathrm{L}}$ was then elicited by a 200-ms depolarizing pulse from -40 to $0 \mathrm{mV}$. Stimulation frequency was $0.2 \mathrm{~Hz}$. The amplitude of $I_{\mathrm{Ca}, \mathrm{L}}$ was measured as the difference between peak inward current and the current remaining at the end of the 200-ms voltage-clamp pulse. For the experiments testing drug effects, cells were exposed to drugs and the effects were monitored by recording $I_{\mathrm{Ca}, \mathrm{L}}$ every $5 \mathrm{~s}$. For the steady-state activation protocol, $\mathrm{HP}$ was $-80 \mathrm{mV}$. Following a 50 -ms prepulse to $-40 \mathrm{mV}, \mathrm{I}_{\mathrm{Ca}, \mathrm{L}}$ was elicited by 200 ms pulses to different test potentials (between -40 and $+50 \mathrm{mV}$ in $10 \mathrm{mV}$ increments). For the steady-state inactivation protocol, HP was $-40 \mathrm{mV}$. 2000-ms conditioning prepulses (between -50 and $0 \mathrm{mV}$ in $10 \mathrm{mV}$ increments) were applied followed by a 200-ms test pulse to $0 \mathrm{mV}$. Stimulation frequency was 0.2 $\mathrm{Hz}$. These measurements were made after a minimal time of 20 min after rupture of the patch to minimize the contribution of time-dependent shifts of steady-state gating parameter measurements.

\section{Data analysis}

Data were analyzed using pClamp 9.0 (Axon instruments) and Sigmaplot 7.0 (SPSS Inc, Chicago, IL, USA). Current density was calculated by dividing the current amplitude by the cell capacitance. The average cell capacitance was $183 \pm 48 \mathrm{pF}$ ( $n=82$ cells). Data from steady-state activation and inactivation relationship of $I_{\mathrm{Ca}, \mathrm{L}}$ were fitted to the Boltzmann equation: $Y=1 /\left\{1+\exp \left[\left(V_{\mathrm{m}}-V_{1 / 2}\right) / k\right]\right\}$, where $V_{\mathrm{m}}$ is the membrane potential, $V_{1 / 2}$ is the half-activation or half-inactivation potential, and $k$ is the slope factor. For steady-state activation curves, $Y$ stands for the relative conductance. The chord conductance was calculated using the ratio of the current to their electromotive for potential in individual current-voltage relationships. Then these conductances were normalized to their individual maximal conductance. For steady-state inactivation curves, $Y$ represents the relative current $\left(I_{\mathrm{Ca}, \mathrm{L}} / I_{\mathrm{Ca}, \mathrm{L}} \mathrm{max}\right)$.

An unpaired Student's $t$-test was perfomed for the comparison between two groups. Significance was tested by oneway analysis of variance (ANOVA) followed by Tukey test if multiple comparisons were made. All values were expressed as mean $\pm S D$, and the number of cells $(n)$ in each group was given. $P<0.05$ was considered to be statistically significant. 


\section{Results}

Biphasic effects of hyposmotic challenge on $I_{\mathrm{Ca}, \mathrm{L}}$

Cells were continuously perfused with an isosmotic solution. Experiments were performed 10 min after establishment of the whole-cell configuration. After the peak inward current had reached a steady state value, the isosmotic external solution was replaced by a hyposmotic external solution.

Figure 1 shows typical traces of $I_{\mathrm{Ca}, \mathrm{L}}$ before and after perfusion with hyposmotic solution. Application of hyposmotic solution always led to a biphasic changes of $I_{\mathrm{Ca}, \mathrm{L}}$. The amplitude of $I_{\mathrm{Ca}, \mathrm{L}}$ increased transiently, then decreased gradually and reached a new steady state value (Figure 1), where the current was able to last for at least $15 \mathrm{~min}$ at this level. Furthermore, the decrease of $I_{\mathrm{Ca}, \mathrm{L}}$ induced by long hyposmotic challenge was accompanied with slowing of the inactivation of $I_{\mathrm{Ca}, \mathrm{L}}$ (Figure 1B inset). However, the time course was variable. $I_{\mathrm{Ca}, \mathrm{L}}$ reached a maximum within $20 \mathrm{~s}-3 \mathrm{~min}$ and a new stable value within 5-10 min after perfusion with hyposmotic solution. After $10 \mathrm{~min}$ of hyposmotic challenge, 8 cells were perfused with isosmotic solution. But the effects of hyposmotic solution on $I_{\mathrm{Ca}, \mathrm{L}}$ could not be reversed (Figure 1). On average, current density of $I_{\mathrm{Ca}, \mathrm{L}}$ was increased to $119.1 \% \pm 6.1 \%$ of control after short exposure (within $3 \mathrm{~min}$ ) (isosmotic: $-4.71 \pm 0.71$ $\mathrm{pA} / \mathrm{pF}$; short hyposmotic: $-5.58 \pm 0.68 \mathrm{pA} / \mathrm{pF}, n=15, P<0.01)$, decreased to $78.1 \% \pm 11.0 \%$ of control after long exposure $(10$ $\mathrm{min}$ ) to hyposmotic solution (long hyposmotic: $-3.65 \pm 0.64 \mathrm{pA} /$ $\mathrm{pF}, n=15, P<0.01$ vs both groups), and recovered to $82.3 \% \pm 9.6 \%$ of control after hyposmotic solution was washed out (washout: $-3.89 \pm 0.74 \mathrm{pA} / \mathrm{pF}, n=8, P>0.05$ vs long hyposmotic) (Figure $1 \mathrm{C})$.

To confirm that the observed changes of $I_{\mathrm{Ca}, \mathrm{L}}$ were due to the osmolarity change, we also studied the effects of hyperosmotic solution on $I_{\mathrm{Ca}, \mathrm{L}}$ in 7 cells. Hyperosmotic challenge increased the amplitude of $I_{\mathrm{Ca}, \mathrm{L}}$ and accelerated the inactivation of $I_{\mathrm{Ca}, \mathrm{L}}$ (Figure 2). Current density of $I_{\mathrm{Ca}, \mathrm{L}}$ was increased to $126.8 .1 \% \pm 11.1 \%$ of control after application of hyperosmotic solution (isosmotic: $-4.93 \pm 0.60 \mathrm{pA} / \mathrm{pF}$; hyperosmotic: $-6.25 \pm 0.96 \mathrm{pA} / \mathrm{pF}, n=7, P<0.05)$ and recovered to $105.5 \% \pm 11.8 \%$ of control after hyperosmotic solution was washed out (washout: $-5.19 \pm 0.61 \mathrm{pA} / \mathrm{pF}, n=6, P>0.05$ vs both groups) (Figure 2C).

We further examined the effects of hyposmotic swelling on the steady-state activation and inactivation curves of $I_{\mathrm{Ca}, \mathrm{L}}$. As shown in Figure $1 \mathrm{~A}, I_{\mathrm{Ca}, \mathrm{L}}$ was increased gradually and could not reach a stable state during short hyposmotic challenge. Thus we only studied the effects of long hyposmotic challenge (10 min) on both curves. Figure 3A shows typical examples of $I_{\mathrm{Ca}, \mathrm{L}}$ recordings obtained with incremental test pulses of the steady-state activation protocol. We again observed that hyposmotic swelling causes reduction of peak $I_{\mathrm{Ca}, \mathrm{L}}$ and slowing of $I_{\mathrm{Ca}, \mathrm{L}}$ inactivation (Figure $3 \mathrm{~A}$ ). The voltage dependence of activation of $I_{\mathrm{Ca}, \mathrm{L}}$ was unaltered (isosmotic: $V_{1 / 2}=-16.51 \pm 1.97$ $\mathrm{mV}, k=6.38 \pm 1.65 \mathrm{mV}, n=21$; hyposmotic: $V_{1 / 2}=-16.85 \pm 2.13$ $\mathrm{mV}, k=7.24 \pm 1.79 \mathrm{mV}, n=6$, both $P>0.05$ vs isosmotic) (Figure $3 \mathrm{~B})$. However, the voltage dependence of inactivation of $I_{\mathrm{Ca}, \mathrm{L}}$ was slightly shifted in the depolarizing direction (isosmotic:
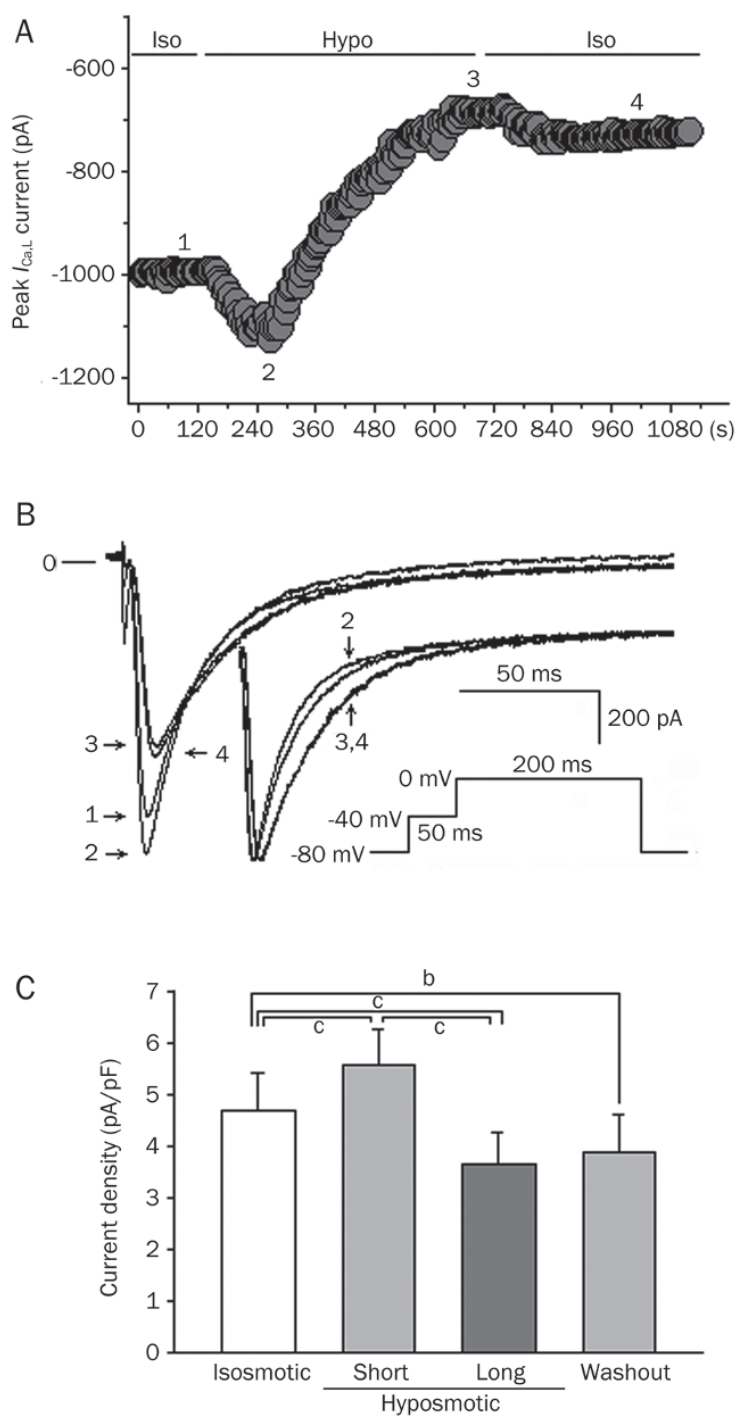

Figure 1. Effects of hyposmotic swelling on $I_{\mathrm{Ca}, \mathrm{L}}$ in rat ventricular myocytes. (A) Time course of peak current measurements from a cell under isosmotic (Iso), hyposmotic (Hypo), and washout conditions. Currents were recorded every 5 s. (B) Representative current traces recorded at different time under different conditions. Inset, currents were normalized to the peak amplitudes and traces were superimposed. Long exposure to hyposmotic solution (3) causes reduction of peak $I_{\mathrm{Ca}, \mathrm{L}}$ and slowing of $I_{\mathrm{Ca}, \mathrm{L}}$ inactivation. These changes of $I_{\mathrm{Ca}, \mathrm{L}}$ could not be reversed by washout (4). (C) The mean current densities of $I_{\mathrm{Ca}, \mathrm{L}}$ under different conditions. Values are Mean \pm SD. $n=8-15$. ${ }^{b} P<0.05,{ }^{c} P<0.01$.

$V_{1 / 2}=-36.78 \pm 2.25 \mathrm{mV}, k=-6.31 \pm 1.45 \mathrm{mV}, n=25$; hyposmotic: $V_{1 / 2}=-33.91 \pm 2.23 \mathrm{mV}, P<0.05$ vs isosmotic, $k=-7.26 \pm 1.44 \mathrm{mV}$, $P>0.05$ vs isosmotic, $n=6$ ) (Figure $3 \mathrm{D}$ ).

Protein kinases, such as PKA, PKC, and PKG, may modulate function of $I_{\mathrm{Ca}, \mathrm{L}}$ channel ${ }^{[23,24]}$. Some studies have reported that hyposmotic swelling modulates function of ion channels by changing activities of protein kinases, such as PKC, tyrosine protein kinase $^{[8,17,25,26]}$. To examine mechanism underlying the hyposmotic swelling-induced biphasic changes of $I_{\mathrm{Ca}, \mathrm{L}}$, we tested whether PKA, PKC, or PKG were involved in the signal 


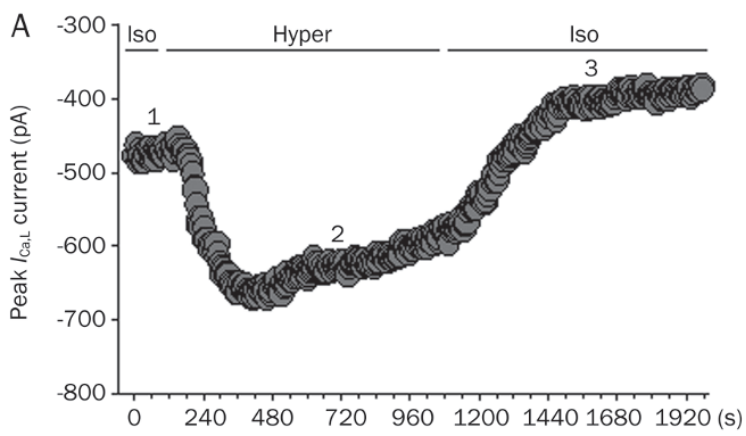

B

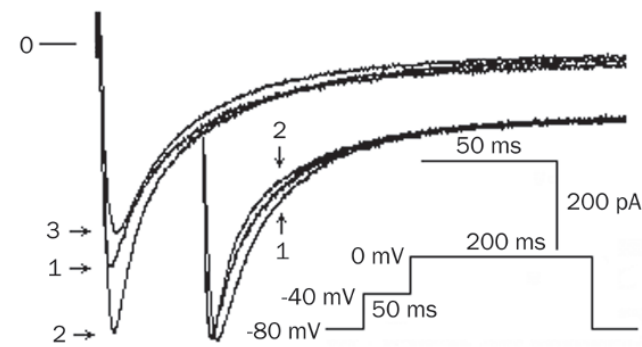

C

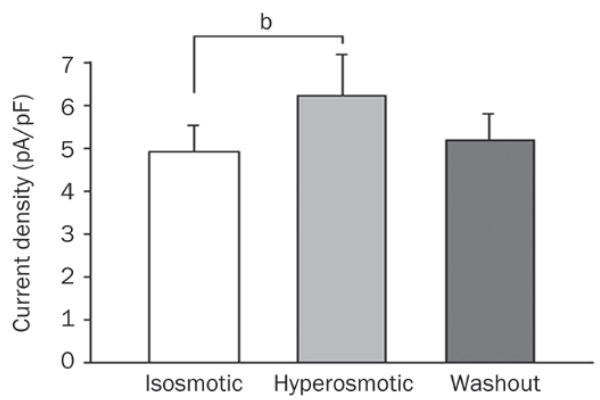

Figure 2. Effects of hyperosmotic challenge on $I_{\mathrm{Ca}, \mathrm{L}}$ in rat ventricular myocytes. (A) Time course of peak current measurements from a cell under isosmotic (Iso), hyperosmotic (Hyper), and washout conditions. Currents were recorded every $5 \mathrm{~s}$. (B) Representative current traces recorded at different time under different conditions. Inset, currents were normalized to the peak amplitudes and traces were superimposed. Hyperosmotic challenge (2) causes enhancement of peak $I_{\mathrm{Ca}, \mathrm{L}}$ and acceleration of $I_{\mathrm{Ca}, \mathrm{L}}$ inactivation. These changes of $I_{\mathrm{Ca}, \mathrm{L}}$ was largely reversible (3). (C) The mean current densities of $I_{\mathrm{Ca}, \mathrm{L}}$ under different conditions. Values are Mean \pm SD. $n=6-7$. ${ }^{\mathrm{b}} P<0.05$.

transduction pathway, respectively.

\section{PKA signaling pathway}

As shown in Figure 4A, application of PKA agonist foskolin $(1 \mu \mathrm{mol} / \mathrm{L})$ under isosmotic conditions significantly increased $I_{\mathrm{C}, \mathrm{L}}$ by $41.3 \% \pm 21.6 \%$ (control: $-5.02 \pm 0.66 \mathrm{pA} / \mathrm{pF}$; foskolin: $-7.05 \pm 1.26 \mathrm{pA} / \mathrm{pF}, n=7, P<0.05)$. Switching the perfusate from isosmotic to hyposmotic solution in the presence of foskolin reverted the prestimulated $I_{\mathrm{Ca}, \mathrm{L}}$ to $90.7 \% \pm 30.9 \%$ of control (hyposmotic+foskolin: $-4.65 \pm 1.98 \mathrm{pA} / \mathrm{pF}, n=7, P<0.05$ vs foskolin) (Figure 4A). In another set of experiments, cells were treated with foskolin after long hyposmotic exposure (10 min).
Again, peak $I_{\mathrm{Ca}, \mathrm{L}}$ was significantly decreased to $79.3 \% \pm 7.1 \%$ of control when cells were exposed to hyposmotic solution (isosmotic: $-5.00 \pm 0.32 \mathrm{pA} / \mathrm{pF}$; hyposmotic: $-3.97 \pm 0.52 \mathrm{pA} / \mathrm{pF}, n=6$, $P<0.05)$. Application of foskolin under hyposmotic conditions significantly reversed the reduced $I_{\mathrm{Ca}, \mathrm{L}}$ to $142.1 \pm 15.4 \%$ of control (hyposmotic+foskolin: $-7.11 \pm 1.00 \mathrm{pA} / \mathrm{pF}, n=6, P<0.01$ vs both groups) (Figure 4B). Similar results were observed in those experiments using $\beta$-adrenergic receptor agonist isoproterenol $(1 \mu \mathrm{mol} / \mathrm{L})$ (data not shown).

To further study the role of PKA in the swelling-induced biphasic changes of $I_{\mathrm{Ca}, \mathrm{L}}$, selective PKA inhibitor H-89 (10 $\mu \mathrm{mol} / \mathrm{L})$ was applied. Cells were dialyzed with a pipette solution containing $\mathrm{H}-89$ for 20 min before the solution change. Treatment with H-89 did not change the amplitude of basal $I_{\mathrm{C}, \mathrm{L}}$ under isosmotic conditions (control: $-6.48 \pm 1.76 \mathrm{pA} / \mathrm{pF}$, $n=44 ; \mathrm{H}-89:-7.51 \pm 1.37 \mathrm{pA} / \mathrm{pF}, n=10, P>0.05)$. In the presence of $\mathrm{H}-89$, hyposmotic swelling still significantly decreased $I_{\mathrm{Ca}, \mathrm{L}}$ to $79.4 \pm 15.2 \%$ of control (isosmotic: $-7.51 \pm 1.37 \mathrm{pA} / \mathrm{pF}$; hyposmotic: $-5.82 \pm 0.79 \mathrm{pA} / \mathrm{pF}, n=10, P<0.01)$. However, H-89 abolished the transient increase of $I_{\mathrm{Ca}, \mathrm{L}}$ induced by hyposmotic swelling in 9 of 10 cells. The biphasic changes of $I_{\mathrm{Ca}, \mathrm{L}}$ was only observed in 1 of 10 cells.

\section{PKG signaling pathway}

Application of NO donor SNAP $(1 \mu \mathrm{mol} / \mathrm{L})$ under isosmotic conditions did not have significant effects on $I_{\mathrm{Ca}, \mathrm{L}}$ (control: $-3.50 \pm 0.24 \mathrm{pA} / \mathrm{pF}$; SNAP: $-3.28 \pm 0.22 \mathrm{pA} / \mathrm{pF}, n=7, P>0.05)$. Switching the perfusate from isosmotic to hyposmotic solution in the presence of SNAP significantly decreased $I_{\mathrm{Ca}, \mathrm{L}}$ to $78.1 \% \pm 13.8 \%$ of control (hyposmotic+SNAP: $-2.75 \pm 0.30 \mathrm{pA} /$ $\mathrm{pF}, n=7, P<0.01$ vs both groups) (Figure $5 \mathrm{~A}$ ). In another set of experiments, cells were treated with SNAP after long hyposmotic exposure $(10 \mathrm{~min})$. Peak $I_{\mathrm{Ca}, \mathrm{L}}$ was significantly decreased after long exposure to hyposmotic solution (isosmotic: $-3.53 \pm 0.47 \mathrm{pA} / \mathrm{pF}$; hyposmotic: $-2.46 \pm 0.22 \mathrm{pA} / \mathrm{pF}$, $n=4, P<0.05)$. Application of SNAP under hyposmotic conditions did not have further effects on $I_{\mathrm{Ca}, \mathrm{L}}$ (hyposmotic+SNAP: $-2.46 \pm 0.33 \mathrm{pA} / \mathrm{pF}, n=4, P>0.05$ vs SNAP) (Figure $5 \mathrm{~A}$ ).

In another 5 cells, selective PKG inhibitor Rp-8-Br-PETcGMPS $(1 \mu \mathrm{mol} / \mathrm{L})$ was applied via the pipette solution. Cells were dialyzed with the pipette solution for $15 \mathrm{~min}$ before the solution change. Treatment with Rp-8-Br-PET-cGMPS did not change the amplitude of basal $I_{\mathrm{Ca}, \mathrm{L}}$ under isosmotic conditions (control: $-6.48 \pm 1.76 \mathrm{pA} / \mathrm{pF}, n=44 ; \mathrm{Rp}-8$-Br-PET-cGMPS: $-5.28 \pm 0.59 \mathrm{pA} / \mathrm{pF}, n=5, P>0.05$ vs control). Under such conditions, hyposmotic swelling still caused the biphasic changes of $I_{\mathrm{Ca}, \mathrm{L}}$ (Figure $5 \mathrm{~B}$ ). These data suggest that PKG system is not involved in swelling-dependent modulation of $I_{\mathrm{Ca}, \mathrm{L}}$.

\section{PKC signaling pathway}

Involvement of PKC in the hyposmotic swelling-induced biphasic changes of $I_{\mathrm{Ca}, \mathrm{L}}$ was evaluated with the PKC activator PMA (100 nmol/L). Application of PMA under isosmotic conditions significantly decreased $I_{\mathrm{Ca}, \mathrm{L}}$ to $80.8 \% \pm 13.8 \%$ of control (control: $-4.05 \pm 0.40 \mathrm{pA} / \mathrm{pF}$; PMA: $-3.28 \pm 0.70 \mathrm{pA} / \mathrm{pF}, n=7$, $P<0.05)$. Interesting, switching the perfusate from isosmotic 
A

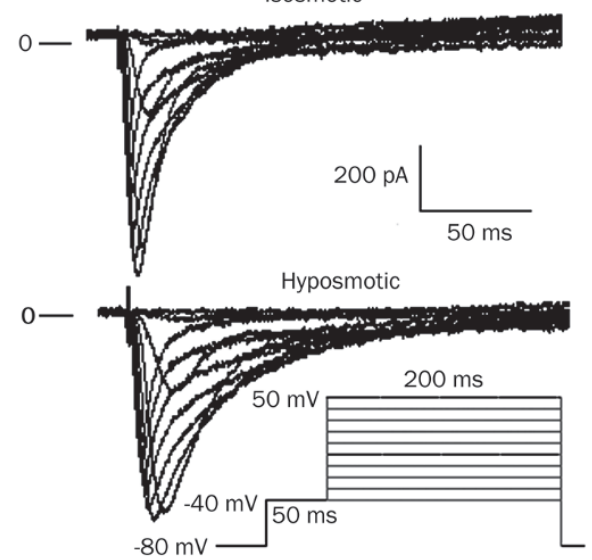

C

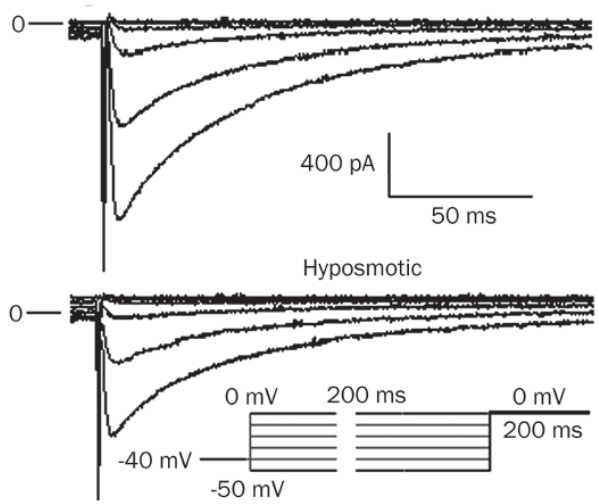

B

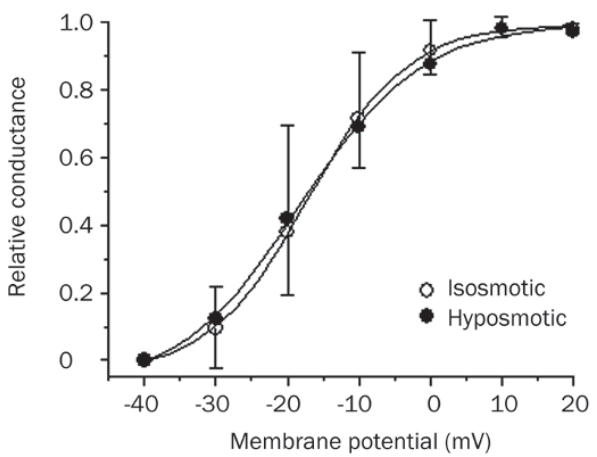

D

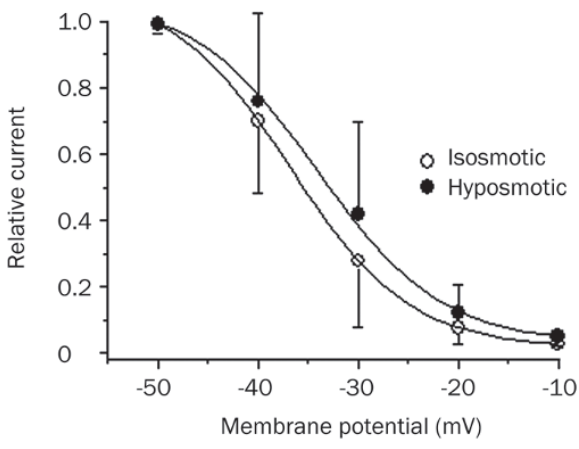

Figure 3. Effects of long hyposmotic challenge on steady-state activation and inactivation curves for $I_{\mathrm{Ca}, \mathrm{L}}$. (A) Examples of $I_{\mathrm{Ca}, \mathrm{L}}$ recordings elicited according to the activation protocol. (B) Comparison of mean activation curves under isosmotic (open circle) and hyposmotic condition (filled circle). Lines represent the fit of data to a Boltzmann distribution function. Hyposmotic swelling does not change the activation curve of $I_{\mathrm{Ca}, \mathrm{L}}$. (C) Examples of $I_{\mathrm{Ca}, \mathrm{L}}$ recordings elicited according to the inactivation protocol. (D) Comparison of mean inactivation curves under isosmotic (open circle) and hyposmotic condition (filled circle). Lines represent the fit of data to a Boltzmann distribution function. Hyposmotic swelling shifts slightly the inactivation curve of $I_{\mathrm{Ca}, \mathrm{L}}$ in depolarizing direction.
A

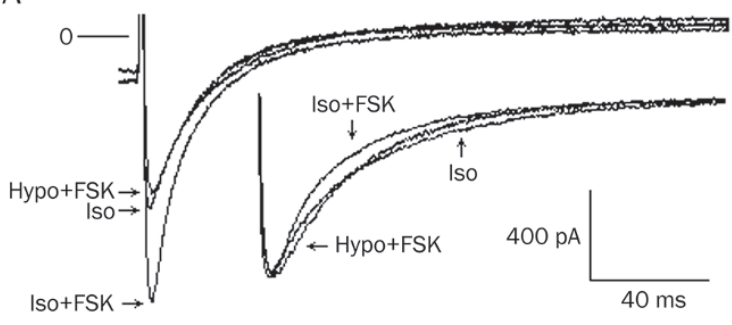

C

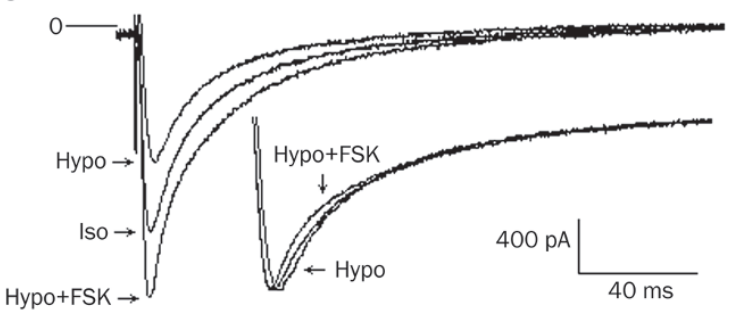

B

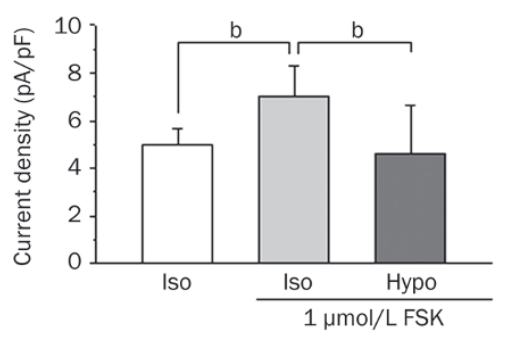

D

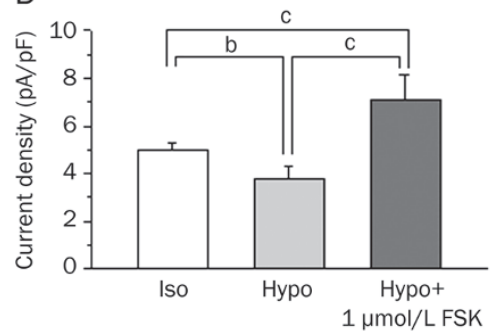

Figure 4. Interactive effects of protein kinase A activator foskolin and hyposmotic swelling on $I_{\mathrm{Ca}, \mathrm{L}}$. (A) Hyposmotic swelling decreases the stimulated $I_{\mathrm{Ca}, \mathrm{L}}$ by foskolin. Left panel shows the representative example of currents recordings in isomostic (Iso), isomostic plus $1 \mu \mathrm{mol} / \mathrm{L}$ foskolin (Iso+FSK), and hyposmotic plus $1 \mu \mathrm{mol} / \mathrm{L}$ foskolin (Hypo+FSK) solution. Right panel shows the mean current density of $I_{\mathrm{Ca}, \mathrm{L}}$ under different conditions. Values are Mean \pm SD. $n=7$. ${ }^{b} P<0.05$. (B) The decreased $I_{\mathrm{Ca}, \mathrm{L}}$ induced by hyposmotic swelling is reversed by foskolin. Left panel shows the representative example of currents recordings in isomostic (Iso), hypomostic (Hypo), and hyposmotic plus $1 \mu \mathrm{mol} / \mathrm{L}$ foskolin (Hypo+FSK) solution. Right panel shows the mean current density of $I_{\mathrm{Ca}, \mathrm{L}}$ under different conditions. Mean \pm SD. $n=6 .{ }^{\mathrm{b}} P<0.05,{ }^{\mathrm{c}} P<0.01$. Inset, currents were normalized to the peak amplitudes and traces were superimposed. 

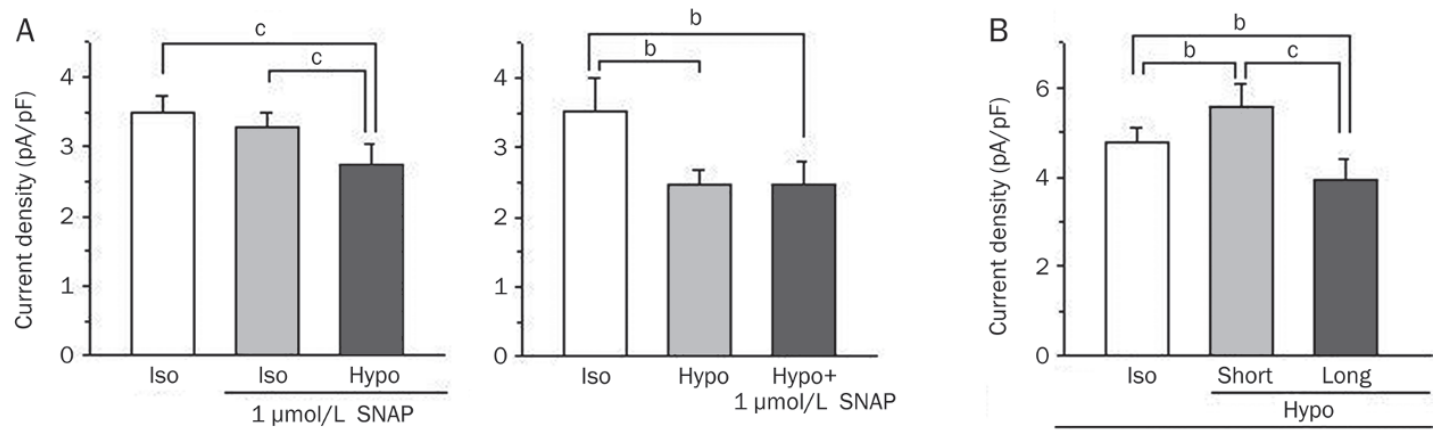

$1 \mu \mathrm{mol} / \mathrm{L}$ Rp-8-Br-PET-cGMPS

Figure 5. Protein kinase $G$ is not involved in swelling-dependent modulation of $I_{\mathrm{Ca}, \mathrm{L}}$. (A) NO donor SNAP does not interference with swelling-dependent modulation of $I_{\mathrm{Ca}, \mathrm{L}}$. The mean current density of $I_{\mathrm{Ca}, \mathrm{L}}$ under different conditions is shown. Data in left panel and right panel are from 7 and 4 cells, respectively. Mean \pm SD. ${ }^{b} P<0.05,{ }^{\mathrm{C}} P<0.01$. (B) PKG inhibitor Rp-8-Br-PET-cGMPS do not block swelling-induced biphasic changes of $I_{\mathrm{Ca}, \mathrm{L}} \cdot 1 \mu \mathrm{mol} / \mathrm{L}$ $\mathrm{Rp}-8$-Br-PET-cGMPS is applied via pipette solution. The mean current density of $I_{\mathrm{Ca}, \mathrm{L}}$ under different conditions is shown. Mean $\pm \mathrm{SD}$. $n=5$. ${ }^{\mathrm{b}} P<0.05$, ${ }^{\mathrm{c}} P<0.01$.

A
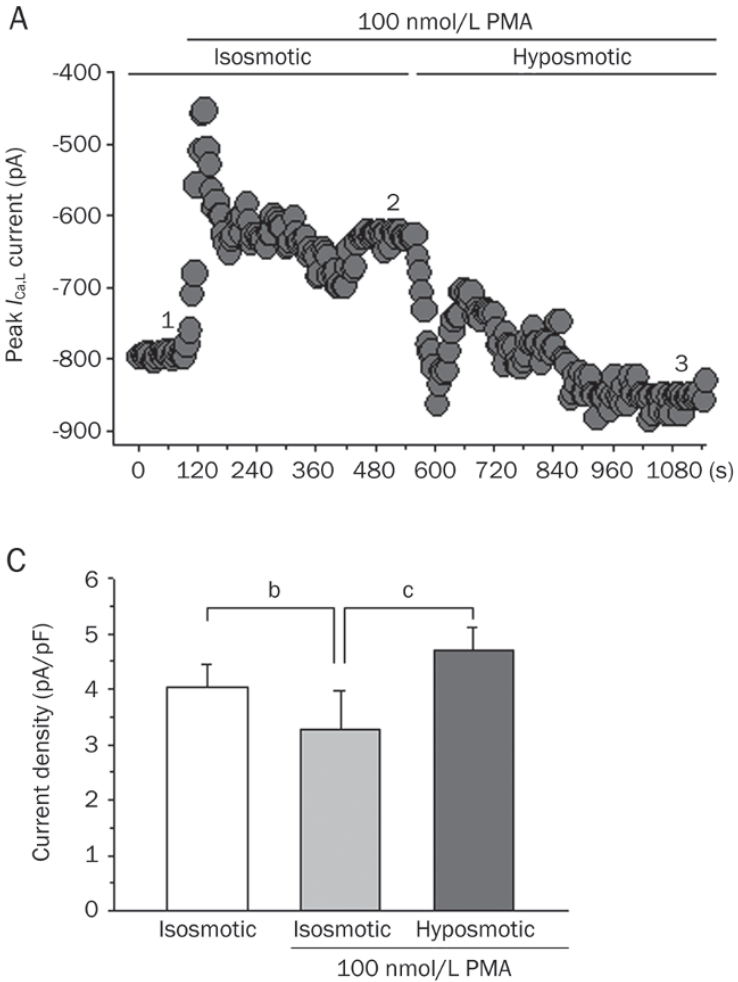

B
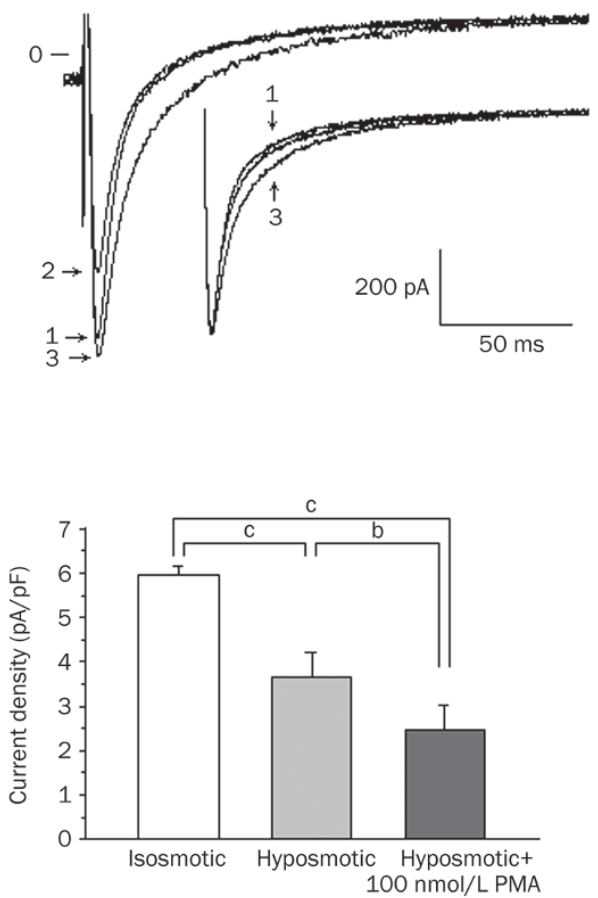

Figure 6. Interactive effects of protein kinase $\mathrm{C}$ activator PMA and hyposmotic swelling on $I_{\mathrm{Ca}, \mathrm{L}}$. (A) Time course of peak current measurements from a cell after application of $100 \mathrm{nmol} / \mathrm{L}$ PMA under isosmotic and hyposmotic conditions. Currents were recorded every $5 \mathrm{~s}$. (B) Representative current traces recorded at different time under different conditions. Inset, currents were normalized to the peak amplitudes and traces were superimposed. PMA decreases $I_{\mathrm{Ca}, \mathrm{L}}$ and slows the inactivation of $I_{\mathrm{Ca}, \mathrm{L}}$. Subsequent application of hyposmotic solution plus PMA reverses PMA-induced decrease of $I_{\mathrm{Ca}, \mathrm{L}}$. (C) The mean current density of $I_{\mathrm{Ca}, \mathrm{L}}$ under different conditions. Values are Mean \pm SD. $n=3-7 .{ }^{b} P<0.05,{ }^{\mathrm{c}} P<0.01$.

to hyposmotic solution in the presence of PMA reversed the decreased $I_{\mathrm{Ca}, \mathrm{L}}$ to $114.3 \% \pm 8.7 \%$ of control (hyposmotic+PMA: $-4.70 \pm 0.40 \mathrm{pA} / \mathrm{pF}, n=5, P<0.01$ vs PMA) (Figure 6). In another set of experiments, cells were treated with PMA after long hyposmotic exposure (10 min). Hyposmotic swelling significantly decreased $I_{\mathrm{Ca}, \mathrm{L}}$ to $64.8 \% \pm 14.8 \%$ of control (isosmotic:
$-5.95 \pm 0.22 \mathrm{pA} / \mathrm{pF}$; hyposmotic: $-3.66 \pm 0.54 \mathrm{pA} / \mathrm{pF}, n=3$, $P<0.01)$. Subsequent application of PMA under hyposmotic conditions further decreased $I_{\mathrm{Ca}, \mathrm{L}}$ to $41.8 \% \pm 11.4 \%$ of control (hyposmotic+PMA: $-2.45 \pm 0.57 \mathrm{pA} / \mathrm{pF}, n=3, P<0.05$ vs hyposmotic) (Figure 6C).

To further evaluate the involvement of PKC in the biphasic 


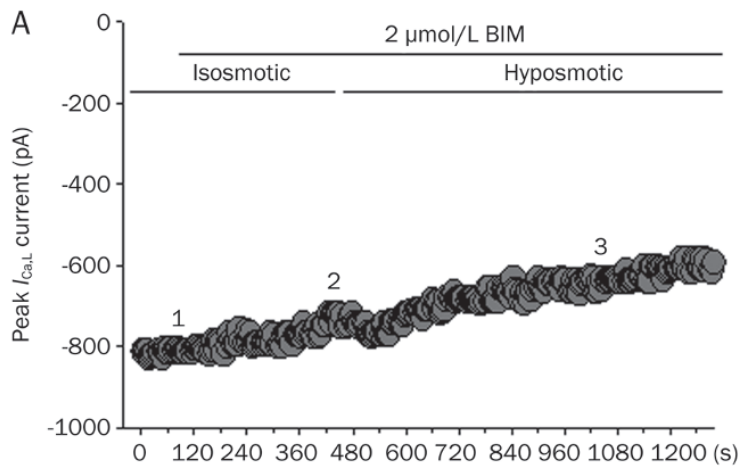

B
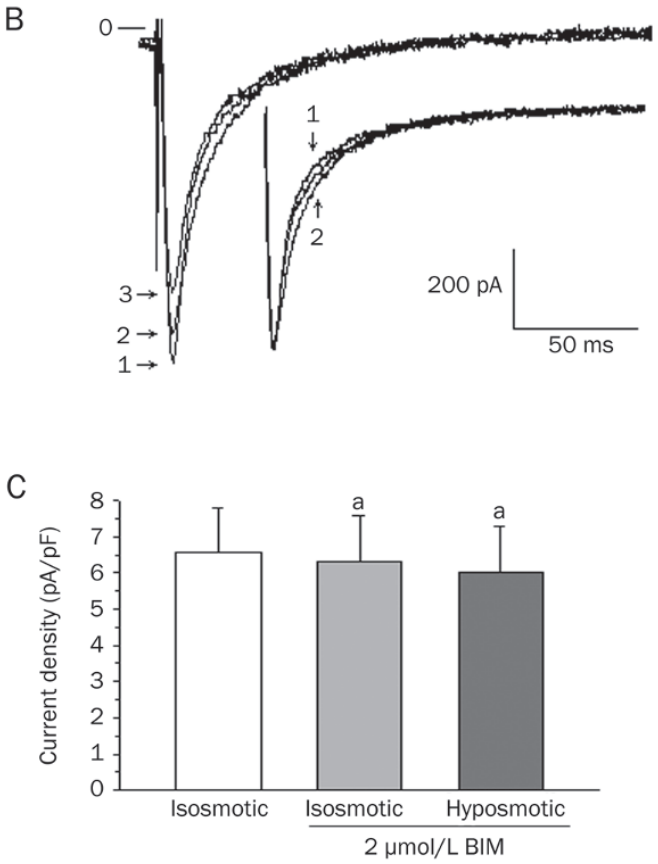

Figure 7. Protein kinase $\mathrm{C}$ inhibitor BIM prevents the swelling-induced biphasic changes of $I_{\mathrm{Ca}, \mathrm{L}}$. (A) Time course of peak current measurements from a cell after application of $2 \mu \mathrm{mol} / \mathrm{L}$ BIM under isosmotic and hyposmotic conditions. Currents were recorded every $5 \mathrm{~s}$. (B) Representative current traces recorded at different time under different conditions. Inset, currents were normalized to the peak amplitudes and traces were superimposed. (C) The mean current density of $I_{\mathrm{Ca}, \mathrm{L}}$ under different conditions. Values are Mean \pm SD. $n=7-10$. ${ }^{a} P>0.05 \mathrm{vs}$ isosmotic.

changes of $I_{\mathrm{Ca}, \mathrm{L}}$ induced by hyposmotic swelling, we treated cells with specific PKC inhibitors BIM $(2 \mu \mathrm{mol} / \mathrm{L})$ before and during exposure to hyposmotic solution. Application of the PKC inhibitor BIM did not have any detectable effects on $I_{\mathrm{C}, \mathrm{L}} \mathrm{under}$ isosmotic conditions. However, BIM prevented the hyposmotic swelling-induced biphasic changes of $I_{\mathrm{Ca}, \mathrm{L}}$. The transient increase of $I_{\mathrm{Ca}, \mathrm{L}}$ was abolished, and $I_{\mathrm{Ca}, \mathrm{L}}$ was decreased slightly by hyposmotic swelling (Figure 7).

\section{Discussion}

Extensive evidence shows that cardiac cells undergo signifi- cant swelling during ischaemia and reperfusion ${ }^{[2-6]}$. During myocardial ischemia, cell metabolites such as inorganic phosphates and lactate accumulate intracellularly and to a certain degree extracellularly. Cardiac myocytes are exposed to a hyposmotic challenge and cell swelling occurs ${ }^{[7]}$. This swelling may be more marked on reperfusion when the hyperosmotic extracellular milieu is replaced by isosmotic blood ${ }^{[4,6,27]}$. It has been shown that cell swelling can modulate the function of a number of membrane channels and ion transporters. These effects will lead to changes in the cardiac electrical activity and may contribute to arrhythmogenesis under pathological conditions $^{[7,8]}$. Many studies have reported that reperfusing hearts with a hyperosmotic perfusate reduces the incidence of reperfusion-induced arrhythmias and results in better recovery of cardiac function $^{[2,3,27,28]}$. Moreover, swelling can also reduce the efficacy of some antiarrhythmic drugs and render them less effective during ischemia/reperfusion ${ }^{[9-11]}$. A full understanding of effects and the mechanisms by which cell swelling modulates function of ion channels and transporters will provide important insights into the electrical effects of myocardial ischemia. In this study we investigated the consequences and mechanisms by which hyposmotic swelling modulates $I_{\mathrm{Ca}, \mathrm{L}}$ in rat ventricular myocytes.

There are controversies in the literature regarding how cell swelling can modulate cardiac $I_{\mathrm{Ca}, \mathrm{L}}$ channel. For example, $I_{\mathrm{Ca}, \mathrm{L}}$ increases in neonatal rat ventricular myocytes ${ }^{[14]}$ and rabbit sinoatrial node and atrial cells $\mathrm{s}^{[12,13]}$, remains unaltered in canine ventricular myocytes ${ }^{[17]}$, decreases or remains unaltered in guinea-pig ventricular myocytes ${ }^{[10,15]}$. Brette et al had reported that in rat ventricular myocytes osmotic swelling decreases $I_{\mathrm{Ca}, \mathrm{L}}{ }^{[16]}$. On the other hand, Li et al had found that in rabbit ventricular myocytes hyposmotic swelling induces biphasic changes, an increase followed by decrease, of $I_{\mathrm{Ca}, \mathrm{L}}$ under perforated whole-cell patch-clamp conditions ${ }^{[18]}$. In the present study, we found that osmotic swelling also induced biphasic changes of $I_{\mathrm{Ca}, \mathrm{L}}$ a transient increase followed by sustained decrease, in rat ventricular myocytes (Figure 1). Our results are similar to the report of $\mathrm{Li}$ et al and different from the report of Brette et al. These contradictory data may be caused by the wide differences in experimental conditions, including different species, tissues, preparations, and the method employed to measure $I_{\mathrm{Ca}, \mathrm{L}}$.

We also compared the effects of hyposmotic swelling and hyperosmotic shrinkage on $I_{\mathrm{C}, \mathrm{L}}$. Hyperosmotic challenge increased amplitude of $I_{\mathrm{Ca}, \mathrm{L}}$ and accelerated inactivation of $I_{\mathrm{Ca}, \mathrm{L}}$ (Figure 2), which was different from that of hyposmotic swelling (Figure 1). When cells are exposed to hyperosmotic solution, cell shrinkage will occur. Then hyperosmotic solution is switched to isomotic solution, now cell swelling will occur. Thus we observed that the increased $I_{\mathrm{Ca}, \mathrm{L}}$ induced by hyperosmotic challenge was reverted after the hyperosmotic solution was washed out (Figure 2), possibly by the same mechanism underlying cell swelling.

We found that NO donor SNAP had no significant effects on the basal $I_{\mathrm{C}, \mathrm{L}}$ in rat ventricular myocytes, which was consistent with previous report ${ }^{[29]}$. SNAP also had no any effects on the 
decreased $I_{\mathrm{Ca}, \mathrm{L}}$ induced by hyposmotic swelling (Figure 5A). Furthermore, PKG inhibitor could not prevent hyposmotic swelling induced biphasic changes of $I_{\mathrm{Ca}, \mathrm{L}}$ (Figure $5 \mathrm{~B}$ ). These results suggest that PKG system is not involved in swellingdependent modulation of $I_{\mathrm{Ca}, \mathrm{L}}$.

The previous reports about the effects of PKC on $I_{\mathrm{Ca}, \mathrm{L}}$ is controversial. Experiments utilizing direct activators of PKC have also demonstrated a range of effects on $I_{\mathrm{Ca}, \mathrm{L}}{ }^{[23,24]}$. In this research, we observed that PKC activator (PMA) decreased the basal $I_{\mathrm{Ca}, \mathrm{L}}$ (Figure 6) and PKC inhibitor (BIM) prevented the biphasic effects of hyposmotic swelling on $I_{\mathrm{Ca}, \mathrm{L}}$ (Figure 7). These results show that PKC system is involved in swellingdependent modulation of $I_{\mathrm{Ca}, \mathrm{L}}$ and hyposmotic swelling may increase PKC activity, which can modulate function of $I_{\mathrm{Ca}, \mathrm{L}}$. In this experiments, we observed an interesting result that the reduced $I_{\mathrm{Ca}, \mathrm{L}}$ induced by PMA was reversed by hyposmotic solution containing PMA (Figure 6). A possible explanation is that, under full activation of PKC by PMA conditions, hyposmotic swelling could act on a signaling system, which can also modulate function of $I_{\mathrm{Ca}, \mathrm{L}}$ channel, and increase $I_{\mathrm{Ca}, \mathrm{L}}$. In this study, we found that PMA could further decrease $I_{\mathrm{Ca}, \mathrm{L}}$ which had been inhibited by hyposmotic swelling (Figure 6C). A PMA concentration of $100 \mathrm{nmol} / \mathrm{L}$ is known to elicit maximum activation of PKC. On the other hand, the degree of activation of PKC by hyposmotic swelling may well be less than that of $100 \mathrm{nmol} / \mathrm{L}$ PMA. This could account for the discrepancy in the quantitative responses to hyposmotic swelling and PMA.

In addition, we found that PKC inhibitor prevented the biphasic effects of hyposmotic swelling on $I_{\mathrm{Ca}, \mathrm{L}}$ and the swelling-induced transient increase of $I_{\mathrm{Ca}, \mathrm{L}}$ also was abolished (Figure 7). On the contrary, in absence of PKC inhibitor, short hyposmotic challenge could result in the transient increase of $I_{\mathrm{Ca}, \mathrm{L}}$ (Figure 1). These results suggest that activation of PKC could be necessary for the swelling-induced transient increase of $I_{\mathrm{Ca}, \mathrm{L}}$. Hyposmotic swelling caused reduction of peak $I_{\mathrm{Ca}, \mathrm{L}}$ and slowing of $I_{\mathrm{Ca}, \mathrm{L}}$ inactivation (Figure 1B, Figure $3 \mathrm{~A}$ ), and shifted rightwardly the steady-state inactivation curve of $I_{\mathrm{Ca}, \mathrm{L}}$ (Figure 3D). PKC activator PMA also had similar effects on $I_{\mathrm{C}, \mathrm{L}}$ (Figure 6B). Thus, these effects of hyposmotic swelling on $I_{\mathrm{Ca}, \mathrm{L}}$ could be associated with swelling-induced activation of PKC.

Extensive literature show that PKA can increase cardiac $I_{\mathrm{C}, \mathrm{L}}$ by phosphorylation of $I_{\mathrm{Ca}, \mathrm{L}}$ channels. In the present study, PKA inhibitor (H-89) abolished the transient increase of $I_{\mathrm{Ca}, \mathrm{L}}$ during short exposure to hyposmotic solution in 9 of 10 cells. It seems that hyposmotic swelling can cause PKA activation, which participates in the transient increase of $I_{\mathrm{Ca}, \mathrm{L}}$ induced by hyposmotic swelling in most cells.

According to our results and above discussion, hyposmotic swelling can cause activation of both PKA and PKC, which participate in the biphasic changes of $I_{\mathrm{Ca}, \mathrm{L}}$ induced by hyposmotic swelling. PKA and PKC have contrary effects on $I_{\mathrm{Ca}, \mathrm{L}}$. Hyposmotic swelling induced monophasic decrease of $I_{\mathrm{Ca}, \mathrm{L}}$ after blocking PKA activity using inhibitor, indicating that swelling-induced PKC activation became the dominant factor in regulation of $I_{\mathrm{Ca}, \mathrm{L}}$ in this situation. We found that hyposmotic swelling could revert PKA enhanced $I_{\mathrm{Ca}, \mathrm{L}}$ (Figure 4A). The activation of PKC inhibits PKA stimulated cardiac $I_{\mathrm{Ca}, \mathrm{L}}{ }^{[30,31]}$, thus we supposed that, under full activation of PKA conditions, PKC could again dominate in swelling-induced changes of $I_{\mathrm{Ca}, \mathrm{L}}$ and decrease PKA stimulated $I_{\mathrm{Ca}, \mathrm{L}}$. In this experiment, activation of PKA could increase the decreased $I_{\mathrm{C}, \mathrm{L}}$ induced by long hyposmotic challenge (Figure 4B), implying that hyposmotic swelling-induced inhibition of $I_{\mathrm{Ca}, \mathrm{L}}$ is reversible in some conditions.

In summary, our present results indicated that hyposmotic challenge induced biphasic changes of $I_{\mathrm{C}, \mathrm{L}}$ a transient increase followed by a sustained decrease, in rat ventricular myocytes through PKC pathway, but not PKG pathway. PKA system could be responsible for the transient increase of $I_{\mathrm{Ca}, \mathrm{L}}$ during short exposure to hyposmotic solution. One limitation of our study is the fact that the current density of $I_{\mathrm{Ca}, \mathrm{L}}$ under basal conditions is quite different among different experiment groups.

\section{Acknowledgements}

This work was supported by the National Natural Science Foundation of China (№ 30700262, № 30400153, № 30670854, № 30200098, and № 30070279) and the Natural Science Foundation of Hubei Province (№ 2002AB128).

\section{Author contribution}

Ming TANG, Jürgen HESCHELER, and An-tao LUO designed the research; An-tao LUO, Hong-yan LUO, Xin-wu HU, Linlin GAO, and Hua-min LIANG performed the research; Antao LUO, Ming TANG, and Jürgen HESCHELER analyzed the data; An-tao LUO and Ming TANG wrote the paper.

\section{References}

1 Hoffmann EK, Simonson LO. Membrane mechanisms in volume and pH regulation in vertebrate cells. Physiol Rev 1989; 69: 315-82.

2 Tranum-Jensen J, Janse MJ, Fiolet JW, D'Alnoncourt CN, Durrer D. Tissue osmolality, cell swelling, and reperfusion in acute regional myocardial ischemia in the isolated porcine heart. Circ Res 1981; 49: 364-81.

3 Powers ER, DiBona DR, Powell WJ Jr. Myocardial cell volume and coronary resistance during diminished coronary perfusion. Am J Physiol 1984; 247: H467-77.

4 Steenbergen C, Hill ML, Jennings RB. Volume regulation and plasma membrane injury in aerobic, anaerobic, and ischaemic myocardium in vitro: effects of osmotic cell swelling on plasma membrane integrity. Circ Res 1985; 57: 864-75.

5 Jennings RB, Reimer KA, Steenbergen C. Myocardial ischaemia revisited. The osmolar load, membrane damage, and reperfusion. J Mol Cell Cardiol 1986; 18: 769-80.

6 Steenbergen C, Hill ML, Jennings RB. Cytoskeletal damage during myocardial ischaemia: changes in vinculin immunofluorescence staining during total in vitro ischemia in canine heart. Circ Res 1987; 60: 478-86.

7 Vandenberg Jl, Rees SA, Wright AR, Powell T. Cell swelling and ion transport pathways in cardiac myocytes. Cardiovasc Res 1996; 32: 85-97. 
8 Cazorla O, Pascarel C, Brette F, Le Guennec JY. Modulation of ions channels and membrane receptors activities by mechanical interventions in cardiomyocytes: possible mechanisms for mechanosensitivity. Prog Biophys Mol Biol 1999; 71: 29-58.

9 Rees SA, Vandenberg J, Wright AR, Yoshida A, Powell T. Cell swelling has differential effects on the rapid and slow components of delayed rectifier potassium current in guinea pig cardiac myocytes. J Gen Physiol 1995; 106: 1151-70.

10 Groh WJ, Gibson KJ, Maylie JG. Hypotonic-induced stretch counteracts the efficacy of the class III antiarrhythmic agent E-4031 in guinea pig myocytes. Cardiovasc Res 1996; 31: 237-45.

11 Wright AR, Rees SA. Targeting ischaemia: cell swelling and drug efficacy. Trends Pharmacol Sci 1997; 18: 224-8.

12 Post JA, Ji S, Leonards KS, Langer GA. Effects of charged amphiphiles on cardiac cell contractility are mediated via effects on $\mathrm{Ca}^{2+}$ current. Am J Physiol 1991; 260: H759-69.

13 Matsuda N, Hagiwara N, Shoda M, Kasanuki H, Hosoda S. Enhancement of the L-type $\mathrm{Ca}^{2+}$ current by mechanical stimulation in single rabbit cardiac myocytes. Circ Res 1996; 78: 650-9.

14 Taouil K, Giancola R, Morel JE, Hannaert P. Hypotonically induced calcium increase and regulatory volume decrease in newborn rat cardiomyocytes. Pflugers Arch 1998; 436: 565-74.

15 Sasaki N, Mitsuiye T, Noma A. Effects of mechanical stretch on membrane currents of single ventricular myocytes of guinea-pig heart. Jpn J Physiol 1992; 42: 957-70.

16 Brette F, Calaghan SC, Lappin S, White E, Colyer J, Le Guennec JY. Biphasic effects of hyposmotic challenge on excitation-contraction coupling in rat ventricular myocytes. Am J Physiol Heart Circ Physiol 2000; 279: H1963-71.

17 Zhou YY, Yao JA, Tseng GN. Role of tyrosine kinase activity in cardiac slow delayed rectifier channel modulation by cell swelling. Pflugers Arch 1997; 433: 750-7.

18 Li GR, Zhang M, Satin LS, Baumgarten CM. Biphasic effects of cell volume on excitation-contraction coupling in rabbit ventricular myocytes. Am J Physiol Heart Circ Physiol 2002; 282: H1270-7.

19 Chen L, Liu C, Liu L. Changes in osmolality modulate voltage-gated calcium channels in trigeminal ganglion neurons. Brain Res 2008; 1208: 56-66.

20 Pascarel C, Brette F, Le Guennec JY. Enhancement of the T-type calcium current by hyposmotic shock in isolated guinea-pig ventricular myocytes. J Mol Cell Cardiol 2001; 33: 1363-9.

21 Wikipedia, the free encyclopedia [homepage on the Internet]. San Francisco: Wikimedia Foundation; 2010 [updated 2010 Jun 11; cited 2010 Jun 21]. Available from: http://en.wikipedia.org/wiki/ Osmolarity.

22 Aggarwal R, Shorofsky SR, Goldman L, Balke CW. Tetrodotoxinblockable calcium currents in rat ventricular myocytes; a third type of cardiac cell sodium current. J Physiol 1997; 505: 353-69.

23 Kamp TJ, Hell JW. Regulation of cardiac L-type calcium channels by protein kinase A and protein kinase C. Circ Res 2000; 87: 1095-102.

24 Keef KD, Hume JR, Zhong J. Regulation of cardiac and smooth muscle $\mathrm{Ca}^{2+}$ channels (Cav1.2a,b) by protein kinases. Am J Physiol 2001; 281: C1743-56.

25 Sorota S. Tyrosine protein kinase inhibitors prevent activation of cardiac swelling-induced chloride current. Pflugers Arch 1995; 431: 178-85.

26 Ding Y, Schwartz D, Posner P, Zhong J. Hypotonic swelling stimulates L-type $\mathrm{Ca}^{2+}$ channel activity in vascular smooth muscle cells through PKC. Am J Physiol 2004; 287: C413-21.

27 Garcia-Doarado D, Oliveras J. Myocardial oedema: a preventable cause of reperfusion injury? Cardiovasc Res 1993; 27: 1555-63.

28 Bernier M, Hearse DJ. Reperfusion-induced arrhythmias: mechanism of protection by glucose and mannitol. Am J Physiol 1988; 254: H862-70.

29 Abi-Gerges N, Fischmeister R, Méry PF. G protein-mediated inhibitory effect of a nitric oxide donor on the L-type $\mathrm{Ca}^{2+}$ current in rat ventricular myocytes. J Physiol 2001; 531: 117-30.

30 Chen L, Sherif EN, Boutjdir M. $\alpha_{1}$-Adrenergic activation inhibits $\beta$-adrenergic stimulated unitary Ca currents in cardiac ventricular myocytes. Circ Res 1996; 79: 184-93.

31 Zhang ZH, Johnson JA, Sherif EN, Boutjdir M. C2 region derived peptides inhibit cardiac Ca channels. Circ Res 1997; 80: 720-9. 